\title{
ELIMINACE POVRCHOVÉ KONDENZACE NA ZASKLENÍ A PŘIPOJOVACÍ SPÁŘE DŘEVĚNÉHO OKNA
}

\author{
ELIMINATION OF SURFACE CONDENSATION ON GLASSING AND \\ CONNECTION JOINTS OF A WOODEN WINDOW
}

\author{
Petra Vorlíčková* ${ }^{*}$, Miloš Kalousek ${ }^{1}$ \\ *vorlickova.p@fce.vutbr.cz \\ ${ }^{1}$ Vysoké učení technické v Brně, Fakulta stavební, Ústav pozemního stavitelství, Veveří 331/95, 60200 Brno, Česká republika
}

\begin{abstract}
Abstrakt
Jedno z nejslabších míst obálky budovy jsou výplně otvorů. Na povrchu oken často klesá teplota pod rosný bod a vzniká povrchová kondenzace. Práce se zabývá studiem nejnižších vnitřních povrchových teplot u dřevěného okna na připojovací spáře zasklení a v místě parapetu. Jako opravný prostředek v nevyhovujícím stavu je použita hliníková lišta různých tlouštěk využívající patentované technologie. Díky vodivosti materiálu je přivedeno teplo do kritické oblasti a zvýšena povrchová teplota. Za pomocí počítačového modelování byly vyzkoušeny varianty provedení lišty a možnosti osazení rámu ve stěně tak, aby bylo dosaženo nejvyšší účinnosti lišty.
\end{abstract}

\section{Klíčová slova}

Povrchová kondenzace, nejnižší vnitřní povrchová kondenzace, okenní zasklení, připojovací spára

\begin{abstract}
One of the weakest points of the building envelope is the filling of the openings. On the surface of the windows, the temperature often drops below the dew point and surface condensation occurs. The work deals with the study of the lowest internal surface temperatures at a wooden window at the connection joints of the glazing and at the location of the window sill. An aluminum strip of various thicknesses using patented technology is used as a remedy. Thanks to the conductivity of the material, heat is brought to the critical area and the surface temperature is increased. With the help of computer modeling, variants of the bar design and the possibility of mounting the frame in the wall were tested in order to achieve the highest efficiency of the bar.
\end{abstract}

Key words

Surface condensation, lowest internal surface condensation, window glazing, connection joint

\section{1 ÚVOD}

Kondenzace na povrchu okenních rámů, parapetů nebo i v místě ostění a překladů je každodenní problém mnoha objektů s obvodovými stěnami bez dodatečného zateplení, navíc po výměně starších dřevěných oken (s vyšší přirozenou infiltrací) za okna modernější (typicky s izolačními dvojskly).

Malou výměnou vzduchu se zvyšuje relativní vlhkost vzduchu v místnosti a nedostatečnými tepelně-technickými vlastnostmi okenních rámů a zasklení klesá nejnižší vnitřní povrchová teplota na nejslabších místech, tj. připojovací spáry zasklení a rámu. Nesmíme přitom zapomínat, že plíseň, která vzniká již při $80 \%$ vlhkosti (povrchová kondenzace až při 100 \% vlhkosti), může být zdraví nebezpečná. Okenní rám je omyvatelný, ovšem pórovitost omítky na ostění zajišt’uje plísni ideální prostředí pro růst a uvolňování spor (nejčastěji těsně nad parapetem). Navíc vlivem vlhkosti degraduje těsnění v připojovací spáře okna a dochází k netěsnostem, které negativně ovlivňují vnitřní mikroklima.

V následující práci byl posuzován detail parapetu s dřevěným oknem a izolačním dvojsklem. Na připojovací spáře zasklení k rámu a rámu ke stěně přitom nebyl splněn požadavek na nejnižší vnitřní povrchovou teplotu dle ČSN 73 0540-2 a jako sanační prostředek byla navržena vodivá lišta z hliníkového plechu [1]. Ta díky své vysoké vodivosti dokáže převést z vnitřního prostředí (nejlépe na styku se vzduchem) dostatek tepla do podchlazeného místa na konstrukci, vycházíme přitom z patentované technologie. 
Cílem práce je zajištění nejlepší efektivnosti použití lišty při různých tloušt'kách plechu $(0,3 \mathrm{~mm}, 0,6 \mathrm{~mm}$ a $0,9 \mathrm{~mm}$ ) a při variaci hloubky uložení zasklení (distančního rámečku) v rámu a dále hloubky osazení okenního rámu ve stěně. Vlastní funkčnost lišty byla již ověřena v předchozích publikacích [2], [3].

\section{LITERÁRNÍ PŘEHLED}

\section{Povrchová teplota}

Na úvod k problematice povrchové kondenzace je důležité objasnit vztah k povrchové teplotě (rosnému bodu). Vlhkost vzduchu rozeznáváme absolutní a relativní. Absolutní vlhkost, jak již napovídá název, určuje přesné množství vlhkosti obsažené ve vzduchu. Má přiřazenu jednotku g/kg a mění se podle využití prostor (kuchyně, koupelna) nebo je například dále zvyšována množstvím květin v místnosti. Oproti tomu velmi často užívaný termín relativní vlhkost je procentuální vyjádření poměru skutečných vodních par ve vzduchu a maximálním obsahem vodních par ve vzduchu pro danou teplotu. V tomto důsledků se v případě zvýšení teploty vzduchu snižuje relativní vlhkost vzduchu (vyšší hranice nasycení vzduchu pro teplejší vzduch - vzduch je schopen pojmout více vzdušné vlhkosti). Pokud se teplota vzduchu bude snižovat (což je nevyhnutný děj, teplota povrchu stěny oproti návrhové teplotě vzduchu v interiéru $-21^{\circ} \mathrm{C} v$ našem př́padě klesla o $6,6{ }^{\circ} \mathrm{C}$ a v místě připojovací spáry nezatepleného okna o $12,7^{\circ} \mathrm{C}$ ), sníží se hodnota nasycení vzduchu (studený vzduch pojme méně vlhkosti) a přiblíží se tak k vyšší relativní vlhkosti vzduchu (nemění se skutečně obsažená vzdušná vlhkost, jen podíl vodních par). Až klesne teplota pod rosný bod, klesne i hodnota maximálního nasycení vzduchu pod hranici relativní vlhkosti (100\%). V této situaci již není vzduch schopen pojmout (udržet) vzdušnou vlhkost a ta bude uvolněna typicky na chladný povrch (např. v místě spáry) formou povrchové kondenzace. Nesmíme přitom zapomínat, že plíseň vzniká již při 80 \% vlhkosti [4].

\section{Vodivost materiálu}

Ve stavebnictví se obecně používají co nejméně vodivé materiály tak, aby bylo dosaženo co možná největších energetických úspor. Je třeba přitom uvažovat i s umístěním jednotlivých materiálů ve skladbě dle jejich tepelnětechnických vlastností. Na interiérové straně není vhodné umist'ovat ty nejlépe izolující materiály. Dochází pak k teplotnímu skoku mezi lehkým izolačním materiálem a těžkou nosnou konstrukcí. Na tomto rozhraní teplot dochází ke kondenzaci difundujících vodních par, což může mít velmi dalekosáhlé následky na funkčnost konstrukce a zdravé vnitřní prostředí. Navíc vnitřní zateplení má mnoho kritérií použitelnosti, odebírá vnitřní prostor, velké tepelné mosty, ... Vnější zateplení naopak umist'uje materiál s nízkou tepelnou vodivostí na exteriérovou stranu tak, aby teploty v konstrukci klesaly rovnoměrněji a nosná konstrukce nebyla podchlazená $\mathrm{v}$ zimním období a $\mathrm{v}$ letním zase přehřátá. Ovšem ne vždy vlze přistoupit $\mathrm{k}$ vnějšímu zateplení a vyřešit problém komplexně.

V případě lokálních problémů (rohy a kouty u věnce/atiky nebo okenní připojovací spáry) může být řešení v použití právě naopak vodivých materiálů. Pokud se na interiérovou stranu aplikuje materiál s vysokou teplotní vodivostí, může vést teplo odebrané z prostředí (omítka/vnitřní vzduch) do kritického místa vykazujícího poruchu. Teorie vedení tepla objasňuje princip vyrovnávání teplot př́mými srážkami molekul [5]. Tento jev není závislý na žádných vnějších zdrojích jako například odporový drát ani nepodléhá rychlé degradaci. Navíc může nastat další pozitivní efekt, kdy vodivý materiál odkloní prostupující vzdušnou vlhkost do konstrukce díky vysokému difuznímu odporu a slouží jako parotěsná přepážka na vnitřní straně konstrukce.

\section{METODIKA}

V následující práci je hodnoceno splnění požadavků na minimální povrchovou teplotu pro stěny a okna dle platné legislativy po přepočtu z teplotního faktoru vnitřního povrchu dle ČSN 73 0540-2, vždy v místě připojovací spáry zasklení na rám a dále rámu na stěnu [1]. V případě nesplnění normových požadavků je jako nápravný prostředek použita patentovaná technologie vodivého materiálu, který je tvarován a lepen na kritické místo v konstrukci. Přesněji je hodnocena hliníková lišta tlouštěk $0,3 \mathrm{~mm}, 0,6 \mathrm{~mm}$ a $0,9 \mathrm{~mm}$. Ta díky své vysoké vodivosti dokáže přivést teplo z prostoru do chladnější oblasti (z oblasti s vyšší kinetickou energií do oblasti s nižší) a zlepšit tak teplotní i vlhkostní stav detailu [5].

Veškeré detaily jsou modelovány v programu Ansys, výpočet metodou konečných prvků. Okrajové parametry simulace byly voleny pro interiér $21^{\circ} \mathrm{C}$, odpor při přestupu tepla na okenním rámu $0,13 \mathrm{~m}^{2} \mathrm{~K} / \mathrm{W}$ a na parapetu $0,25 \mathrm{~m}^{2} \mathrm{~K} / \mathrm{W}$ a pro exteriér $-15^{\circ} \mathrm{C}$, odpor při přestupu tepla na vnější straně $0,04 \mathrm{~m}^{2} \mathrm{~K} / \mathrm{W}$. Hodnota rosného bodu pro tyto okrajové podmínky při $50 \%$ relativní vlhkosti v interiéru činí $11.58{ }^{\circ} \mathrm{C}$ pro stěny a $8,25^{\circ} \mathrm{C}$ pro okna. 


\section{VÝSLEDKY}

V následujícím hodnocení byl analyzován detail parapetu s dřevěným okenním rámem a s izolačním dvojsklem osazen na zděné stěně tloušt'ky $60 \mathrm{~cm}$. Nejdříve byla zkoumána efektivnost aplikace vybrané lišty různých tlouštěk na zasklení při různých hloubkách zapuštění distančního rámečku. Dále byla zkoumána aplikace vybraných lišt různých tlouštěk na připojovací spáru okna při variaci umístění rámu ve stěně. Z důvodu zjednodušení práce s materiálem, jeho ohýbání a lepení byla lišta rozdělena na dva kusy a modelována i s možnou mezerou v místě parapetu.

\section{Lišta na zasklení}

Vybraná lišta celkové délky $50 \mathrm{~mm}$ (výška lišty na zaklení $5 \mathrm{~mm}$ ) byla zkoušena ve 3 variantách tlouštěk plechu (0,3 mm, 0,6 mm, 0,9 mm) a pro 3 hloubky zapuštění zasklení $(20 \mathrm{~mm}, 25 \mathrm{~mm}, 30 \mathrm{~mm})$. Výsledky lze vidět v grafu níže (viz. Obr. 1, b). Nejnižší vnitřní povrchové teploty na zasklení bez jakékoli úpravy jsou pro hloubku distančního rámečku $20 \mathrm{~mm}-5,01{ }^{\circ} \mathrm{C}, 25 \mathrm{~mm}-7,43{ }^{\circ} \mathrm{C}$ a pro $30 \mathrm{~mm}-8,64{ }^{\circ} \mathrm{C}$.
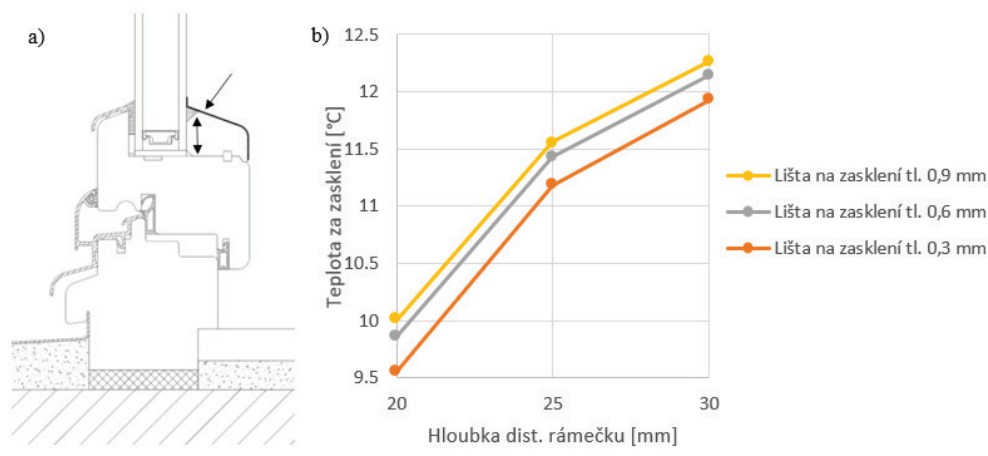

Obr. 1 Dřevěný okenní rám s hliníkovou lištou na okenním zasklení a) schéma, b) graf závislosti teploty na zasklení na hloubce zapuštění zasklení.

\section{Lišta na rámu v místě parapetu}

Ve druhé části byla lišta umístěna na připojovací spáře parapetu. Modelována byla lišta v délce kolem celé šířky parapetu, a to ve variantách - lišta pouze vodorovná, lišta se svislou částí na rámu (výška $35 \mathrm{~mm}$ ) a v neposlední řadě lišta s přerušením mezi vodorovnou a svislou částí velikosti $0,1 \mathrm{~mm}$ a $1 \mathrm{~mm}$ (viz. Obr. 2 - schémata). Variováno bylo umístění rámu ve stěně, směrem od interiéru byl nejdříve umístěn rám ve vzdálenosti $150 \mathrm{~mm}$, dále $300 \mathrm{~mm}$ (na střed) a do exteriéru $450 \mathrm{~mm}$. Výsledky lze vidět v grafu níže (viz. Obr. 3). Nejnižší vnitřní povrchové teploty na připojovací spáře okna bez úpravy lištou je pro hloubku zapuštění $150 \mathrm{~mm}-9,24{ }^{\circ} \mathrm{C}$, $300 \mathrm{~mm}-8,3{ }^{\circ} \mathrm{C}$ a $450 \mathrm{~mm}-7,20{ }^{\circ} \mathrm{C}$.
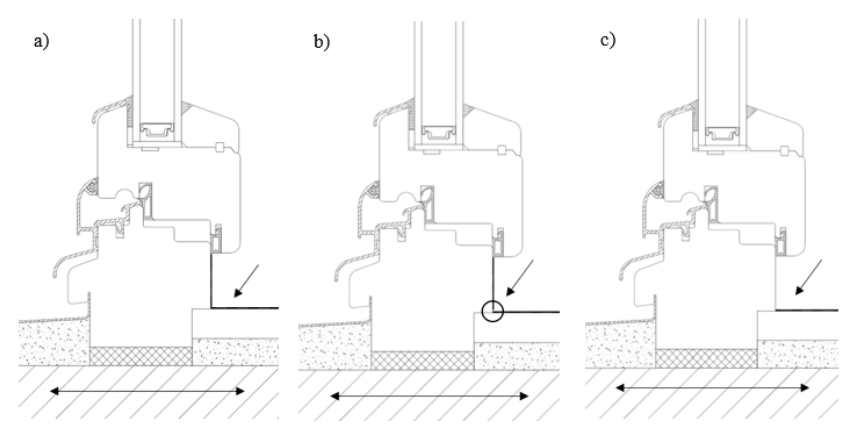

Obr. 2 Dřevěný okenní rám s hliníkovou lištou na parapetu a) lišta bez přerušení, b) lišta přerušená $0,1 \mathrm{~mm}$ a $1 \mathrm{~mm}, \mathrm{c})$ lišta pouze vodorovná. 


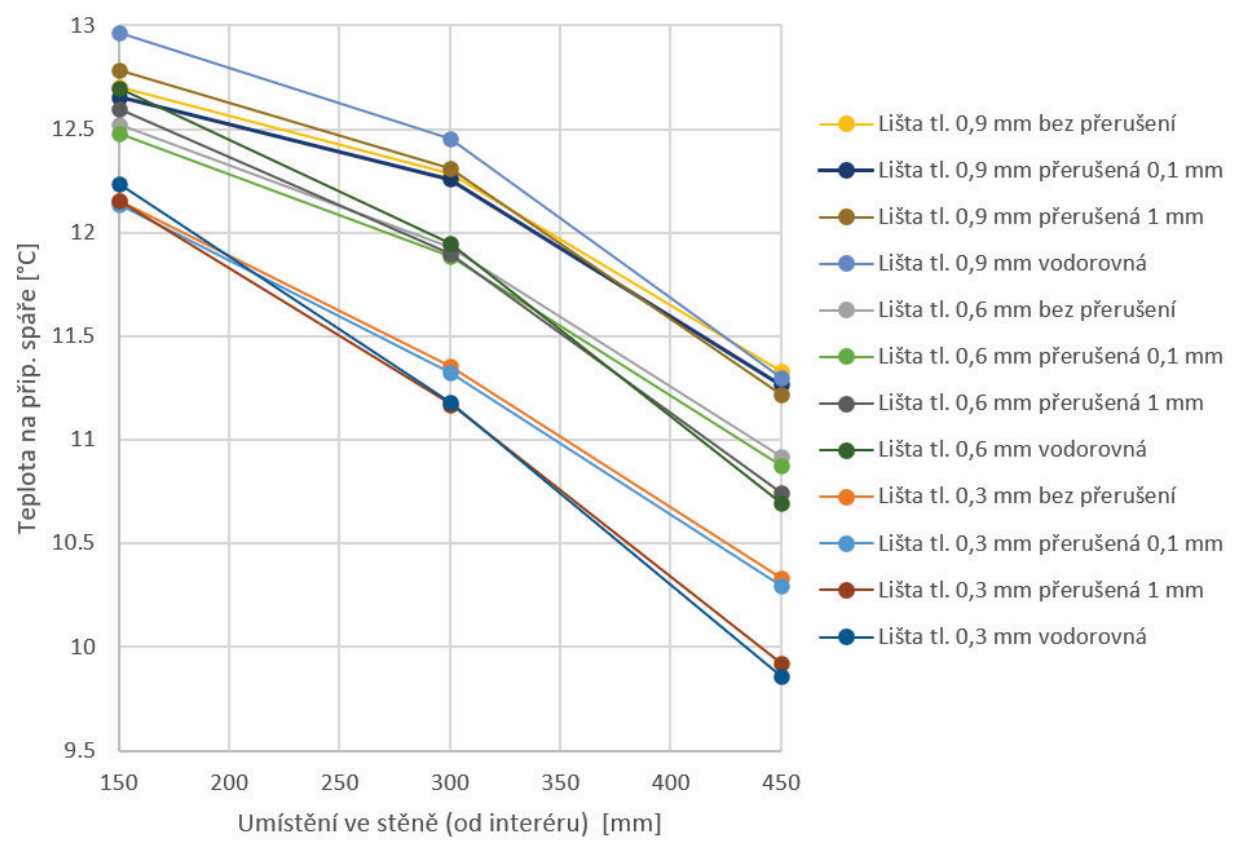

Obr. 3 Graf závislosti teploty na připojovací spáře na hloubce umístění rámu v ostění.

\section{DISKUZE}

V předchozích publikacích byla prokázána funkčnost aplikace hliníkové lišty na okno, respektive zvýšení nejnižší povrchové teploty na připojovací spáře parapetu a zaklení a také zabránění difuze vodní páry v místě připojovací spáry okna ke stěně [2], [3].

\section{Lišta na zasklení}

Z výsledků vyplývá, že s větší hloubkou zapuštění distančního rámečku do rámu se zvyšuje povrchová teplota v místě připojovací spáry zasklení na rám. Důvodem může být oddálení slabého místa zasklení (spojení tabuli přes distanční rámeček) hlouběji do rámu. Bohužel s větší hloubkou zapuštění klesá estetická hodnota okna, také se komplikuje montáž větších okenních tabulí a zvětšují se rozměry rámu (což vede k větší masivnosti rámu a menšímu osvětlení vnitřních prostor). Mírný rozdíl bychom mohli zpozorovat, pokud bychom ve výpočtu zohledňovali proudění vzduchu (plynu) mezi zasklením, který u izolačních dvojskel výrazněji ovlivňuje povrchovou teplotu.

Po aplikaci lišty došlo $\mathrm{k}$ nárůstu teploty ve všech případech. V chování lišty vidíme větší teplotní rozdíl mezi lištou tloušt'ky $0,3 \mathrm{~mm}$ a $0,6 \mathrm{~mm}\left(0,3{ }^{\circ} \mathrm{C}\right)$ a menší mezi lištami tlustými $0,6 \mathrm{~mm}$ a $0,9 \mathrm{~mm}\left(0,15^{\circ} \mathrm{C}\right)$. Největší efektivnosti lišta dosáhla při nejnižší vstupní teplotě, tj. u nejnižší hloubky zapuštění distančního rámečku (20 mm). Svou účinnost prokázala již lišta s tloušt'kou $0,3 \mathrm{~mm}$.

\section{Lišta na parapetu}

Po aplikaci lišty došlo k očekávanému nárůstu teploty v připojovací spáře okna. Směrem k interiéru (hodnota na vodorovné ose $150 \mathrm{~mm}$ ) je nejvýhodnější lišta pouze vodorovná. Kratší vodorovná část na parapetu přivede teplo do připojovací spáry dostatečně efektivně a svislá část odčerpává teplo pro studený rám. Proto teplota lišty s mezerou $1 \mathrm{~mm}$ a především pouze vodorovná lišta oproti liště nepřerušené stoupá. Směrem do exteriéru $(450 \mathrm{~mm})$ se projevilo očekávané zhoršení teploty vlivem větší spáry a jako nejvýhodnější se jeví lišta bez přerušení. Nejtenčí lišta $(0.3 \mathrm{~mm})$ je nejvíce závislá na nepřerušenosti materiálu a nevyplatí se dávat směrem do exteriéru. Lišta s mezerou $0,1 \mathrm{~mm}$,kopíruje" chování lišty bez přerušení s menší účinností (lišta tl. $0,3 \mathrm{~mm}$ 
umístěná na okně nejblíže interiéru vykazuje nejmenší rozdíl teplot, lišta tl. 0,9 mm umístěná k exteriéru největší). Nejvyššího nárůstu teplot dosáhla vodorovná lišta tl. $0.9 \mathrm{~mm}$ při osazení okna na střed stěny.

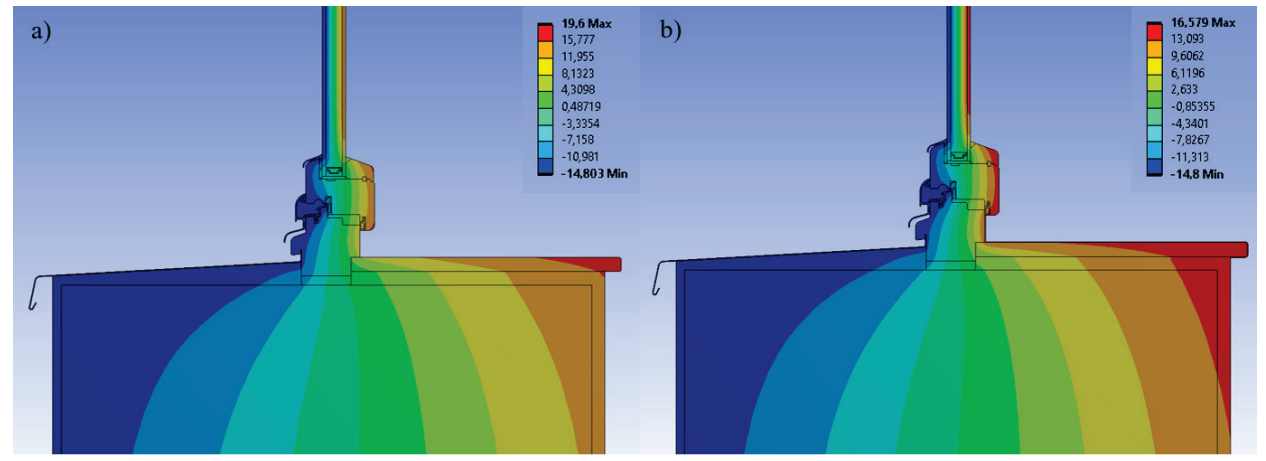

Obr. 4 Průběhy teplost detailu parapetu a) bez úpravy, b) s nepřerušenou lištou 0,9 mm kolem celého parapetu.

\section{ZÁV̌̌R}

Za účelem eliminace povrchové kondenzace na okenním zasklení a rámu v místě parapetu byla aplikována hliníková lišta na interiérové straně. Tento vodivý materiál dokáže zlepšit nevyhovující stav nad teplotu rosného bodu a zamezit tak povrchové kondenzaci. V práci byla variována hloubka zapuštění zasklení a dále hloubka uložení rámu ve stěně před a po aplikaci lišty na zasklení a dále parapet. Byly vyzkoušeny 3 tloušt'ky hliníkového plechu, všechny prokázaly účinnost. Lišta tloušt'ky $0,3 \mathrm{~mm}$ dosáhla dle očekávání nejnižšího nárůstu teplot, lišta 0,9 mm nejvyššího.

V případě aplikace lišty na parapet byly pozorovány rozdílné průběhy teplot dle zvoleného tvaru lišty a dle hloubky osazení rámu ve stěně. Směrem do exteriéru se jeví nejvýhodněji lišta bez přerušení, směrem do interiéru lišta pouze vodorovná na parapetu bez části na rámu.

\section{Použité zdroje}

[1] ČSN 73 0540-2:2011 Tepelná ochrana budov - Č́st 2: Požadavky. Z1. Praha: ÚNMZ, 2012.

[2] VORLÍČKOVÁ, P.; KALOUSEK, M. Zamezení vzniku kondenzace na okenním zasklení a v připojovací spáře. In JUNIORSTAV 2021. 23. odborná konference doktorského studia s mezinárodní účastí. Brno: Vysoké učení technické v Brně, Fakulta stavební, 2021. s. 765-770. ISBN: 978-80-86433-75-2

[3] VORLÍČKOVÁ, P.; KALOUSEK, M. Možnosti zvýšení povrchové teploty nad rosný bod na připojovací spáře a zasklení okna. In JUNIORSTAV 2020. 22. odborná konference doktorského studia s mezinárodní účastí. Brno: Vysoké učení technické v Brně, Fakulta stavební, 2020. s. 918-924. ISBN: 978-80-86433-73-8.

[4] PAPRANEC, Michal a David BEČKOVSKÝ. Faktory ovlivňující vnitřní povrchovou teplotu a kondenzaci na povrchu konstrukcí - Díl 1. TZB-info [online]. 2012. Dostupné z: https://stavba.tzbinfo.cz/vlhkost-a-kondenzace-v-konstrukcich/9134-faktory-ovlivnujici-vnitrni-povrchovou-teplotu-akondenzaci-na-povrchu-konstrukci-dil-1

[5] ADMIN E-KONSTRUKTÉR. Jaký je rozdíl mezi přenosem tepla vedením, prouděním a sáláním?. Ekonstruktér [online]. 2015. Dostupné z: https://e-konstrukter.cz/novinka/jaky-je-rozdil-meziprenosem-tepla-vedenim-proudenim-a-salanim 